\title{
Poczucie humoru oraz pozytywna orientacja na siebie i świat w kontekście osobowościowych różnic indywidualnych
}

\section{Sense of humour and positive orientation to the self and to the world in the context of individual personality differences}

\author{
Anna Starkowska ${ }^{\boxplus}$, Daria Suchecka1', Joanna Kotowska², Monika Mak \\ ${ }^{1}$ Pomorski Uniwersytet Medyczny w Szczecinie, Katedra i Klinika Psychiatrii, Samodzielna Pracownia Psychologii Klinicznej, ul. Broniewskiego 26, 71-460 Szczecin \\ Pomeranian Medical University in Szczecin, Department of Psychiatry, Independent Clinical Psychology Unit \\ 2 Międzyuczelniane Koło Naukowe Psychologii Klinicznej,Psyche” \\ Intercollegiate "Psyche" Student Research Group \\ $\triangle$ a.starkowska.pum@gmail.com
}

\begin{abstract}
Introduction: The aim of this paper describes the relationships between relatively stable personality traits, styles of humour and strength of positive orientation to the self and the external world. Good humour and a positive attitude are considered factors of health, by supporting a state of psychophysiological well-being and mediating the process of treating mental disorders, as well as physical illnesses.

The aim of the study was to identify personality traits related to constructive humour and a positive orientation to life, and thus promoting general well-being and motivation to take care of one's own health and psychophysical condition.

Materials and methods: A questionnaire-based survey involved a group of 68 students of two social and medical universities in Szczecin (66\% women, $34 \%$ men) aged 20 to 49 years ( $M=24,5$;
\end{abstract}

$S D=6.4)$. Three standardized psychological test were used: the Eysenck Personality Questionnaire EPQ-R, the Humour Styles Questionnaire HSQ, and The Positivity Scale.

Results: The survey indicated the positive impact of extraversion (associated with a higher general sense of humour and aggressive humour), and a reduced need for social approval (associated with affiliative humour), as well as the negative impact of neuroticism, which was associated with higher masochistic humour, lower self-enhancing humour, and decreased positive orientation. Conclusions: The study suggests that a personality profile characterised by openness to people and the external world, and at the same time emotionally balanced, with a predominance of positive feelings is preferred from the point of view of a positive attitude.

Keywords: personality; humour; positive orientation; well-being.

\begin{abstract}
ABSTRAKT
Wstęp: W pracy opisano zależności zachodzące pomiędzy względnie stałymi cechami osobowości a stylami poczucia humoru oraz siłą pozytywnej orientacji na siebie i świat. Dobry humor i pozytywne nastawienie uznawane są za czynniki zdrowia, które wspomagają utrzymanie dobrostanu psychofizycznego i pośredniczą w procesie leczenia zarówno zaburzeń psychicznych, jaki chorób fizycznych.

Celem pracy było wyodrębnienie dyspozycji osobowościowych, które wiążą się z konstruktywnym humorem i pozytywną orientacją na siebie i świat.

Materiały i metody: Badaniem kwestionariuszowym objęto grupę 68 studentów szczecińskich uczelni wyższych (66\% kobiet, $34 \%$ mężczyzn) w wieku 20-49 lat ( $M=24,5$; $S D=6,4)$. Wykorzystano Kwestionariusz Osobowości EPQ-R, Kwestionariusz Stylów Humoru HSQ oraz Skalę Orientacji Pozytywnej.
\end{abstract}

Wyniki: Wykazano korzystne znaczenie ekstrawersji (związanej z humorem ogólnym i agresywnym) oraz obniżonej potrzeby aprobaty społecznej (związanej z humorem afiliacyjnym). Niekorzystne związki zachodziły w odniesieniu do cechy neurotyzmu, co wiązało się z wysokim humorem masochistycznym, niskim humorem w służbie ego oraz niższą orientacją pozytywną, a także cechy psychotyzmu, wzmagającej agresywny styl żartu.

Wnioski: Z punktu widzenia pozytywnego nastawienia do siebie i innych korzystny wydaje się profil osobowości otwartej na ludzi i świat zdarzeń zewnętrznych, a przy tym emocjonalnie zrównoważonej, z przewagą uczuć pozytywnych i o łagodnym usposobieniu.

Słowa kluczowe: osobowość; humor; orientacja pozytywna; dobrostan psychofizyczny.

\section{WSTĘP}

Dobry humor i pozytywne nastawienie, będące rodzajem psychologicznych zasobów człowieka, ułatwiają radzenie sobie ze stresem i problemami $[1,2]$ oraz wiążą się z ogólnie lepszą oceną zdrowia fizycznego i psychicznego [3, 4]. Śmiech i dobry nastrój mają korzystny wpływ na zmniejszenie nasilenia objawów zaburzeń nastroju [5] oraz psychotycznych [6], wspomagają również proces leczenia chorób somatycznych, redukując smutek i lęk, a także zmniejszając ból, poprawiając wydolność oddechową i jakość snu oraz zwiększając biologiczną odporność organizmu [7]. Pozytywne nastawienie związane jest 
także z łagodniejszym przebiegiem chorób nowotworowych i zakażenia wirusem HIV [8].

Różnice indywidualne w zakresie natężenia oraz określonych stylów poczucia humoru powszechnie występujące między ludźmi mogą być zależne od wieku, płci, kultury czy wychowania, a także od indywidualnych predyspozycji psychicznych takich jak cechy osobowości. Z tego powodu niektórzy śmieją się więcej niż inni i nie każdy gustuje w tych samym żartach.

Osobowość rozumiana jest jako względnie stały zespół cech, które predysponują do określonego zachowania w odpowiedzi na konkretne bodźce. Poznając indywidualny układ cech osobowości, można (z mniejszą lub większa dokładnością) przewidywać zachowania ludzi w różnych sytuacjach życia codziennego, w tym także zachowania zdrowotne. Dyspozycje te kształtują się pod wpływem indywidualnych doświadczeń zdobywanych w ciągu życia, zaś ich bazą są wrodzone cechy temperamentalne, które opisują typowy dla danej jednostki sposób działania układu nerwowego (m.in. jego pobudliwość czy zapotrzebowanie na stymulację) [9]. Dyspozycje osobowościowe to jedne z głównych filtrów psychologicznych człowieka, które warunkują sposób odbioru świata i reagowania na niego, tworząc podstawę różnic indywidualnych powszechnie występujących u zdrowych ludzi. Ich skrajne nasilenia mogą predysponować do rozwoju zaburzeń, w tym depresyjnych, lękowych, psychotycznych czy uzależnień od substancji psychoaktywnych [10].

\section{Trójczynnikowa teoria osobowości Hansa Eysencka}

Najbardziej rozpowszechnionym ujęciem osobowości jest teoria „wielkiej piątki” [11], która wykorzystywana była w wielu badaniach, w tym dotyczących humoru [12]. Obok niej popularna jest również koncepcja Hansa Eysencka, która zakłada istnienie trzech głównych dyspozycji - ekstrawersji (E), neurotyzmu $(\mathrm{N})$ i psychotyzmu $(\mathrm{P})$, opisujących różnice indywidualne w zakresie funkcjonowania poznawczego, emocjonalnego i społecznego.

Zgodnie z założeniami tej koncepcji ekstrawertyka charakteryzuje otwartość na świat doznań zewnętrznych i potrzeba kontaktów z innymi ludźmi. Osoby takie poszukują zwykle silniejszej stymulacji i wrażeń, są spontaniczne, aktywne i towarzyskie. Przeciwieństwem ekstrawersji jest introwersja (ukierunkowanie uwagi na świat przeżyć wewnętrznych), która wiąże się ze zdystansowaniem wobec otoczenia, przy jednoczesnym silnym wglądzie we własne myśli, uczucia i zachowanie.

Przeciwieństwem drugiej cechy - neurotyzmu - jest stabilność emocjonalna. Osoba neurotyczna cechuje się lękliwością, chwiejnością nastrojów, przewagą emocji negatywnych. Może być skłonna do zamartwiania się, niepewności, a także mieć depresyjne nastroje i obniżoną samoocenę.

Wymiar psychotyzmu natomiast rozciąga się od cech społecznie akceptowalnych aż po zachowania przestępcze, psychopatyczne oraz podatność na poważne zaburzenia psychiczne, np. schizofrenię. Pomimo psychopatologii zawartej w tym określeniu H. Eysenck zaznaczył, że jego model psychotyzmu wskazuje na cechy mieszczące się w normach społecznych, które nabierają patologicznego wydźwięku dopiero w skrajnych przypadkach. Dlatego wysoki wynik w skali P określa zdrowego człowieka jako stroniącego od ludzi indywidualistę, o obniżonej emocjonalności i potrzebach społecznych, który może mieć problem w podporządkowaniu się zasadom społecznym i prawnym czy wykazy wać dziwaczne upodobania [13,14].

\section{Humor i orientacja pozytywna oraz ich związki z dyspozycjami osobowościowymi}

Rozwój psychologii pozytywnej i poszczególnych jej działów skierował uwagę naukowców na rolę humoru w kształtowaniu dobrego samopoczucia jednostki. Humor i śmiech to mechanizmy regulujące psychofizyczną równowagę, przyczyniające się do łagodzenia dolegliwości somatycznych, w tym redukowania przewlekłego bólu. Nie tylko zmniejszają napięcie wywołane przez stres [15], lecz także spełniają rolę wychowawczą, edukacyjną, komunikacyjną, intelektualno-twórczą, światopoglądową i wspierającą zdrowie fizyczne [16].

Spośród teoretycznych ujęć humoru na uwagę zasługuje koncepcja Roda Martina [17] łącząca pozytywne i negatywne style używania humoru oraz wyróżniająca cztery jego rodzaje:

1. Humor afiliacyjny sprzyja tworzeniu relacji interpersonalnych i przyjaznej atmosfery otoczenia. Związany jest z ogólną wesołością, pozytywną samooceną, satysfakcją z nawiązanych relacji oraz dominacją pozytywnego nastawienia do otoczenia.

2. Humor w służbie ego stosowany jest w sytuacjach stresujących do zwalczania wewnętrznego napięcia i celem podniesienia samooceny. To umiejętność dostrzegania w życiu zabawnych sytuacji. Jego poziom jest proporcjonalny do poziomu samooceny i subiektywnego dobrostanu.

3. Humor agresywny uaktywnia się (często nawykowo) w celu podniesienia samooceny, ale kosztem wywołania dyskomfortu lub poczucia krzywdy innych osób. Często towarzyszą mu trudności w hamowaniu impulsu mówienia śmiesznych rzeczy. Ten styl koreluje ujemnie z satysfakcją ze związków, a dodatnio z poziomem agresji, wrogości i gniewu. Nacechowany jest wieloma negatywnymi emocjami.

4. Humor samodeprecjonujący (masochistyczny) stosowany jest w celu zbliżenia się do innych osób i zdobycia ich aprobaty, ale kosztem własnej osoby, np. poprzez samoponiżanie i ośmieszanie. Ten styl współwystępuje z niskim odczuwanym poziomem dobrostanu psychicznego i wysokim poziomem lęku. Osobę o tym stylu charakteryzuje obniżony nastrój oraz niska samoocena, a także mniejszy poziom odczuwania satysfakcji z kontaktów intymnych [18].

Ogólne zadowolenie, związane z poszukiwaniem optymistycznych aspektów życia, łączy się też z teorią orientacji pozytywnej (myśleniem pozytywnym). Jest to podstawowa, ogólna tendencja do zauważania i wysokiego wartościowania dodatnich aspektów życia codziennego, przebytych doświadczeń oraz własnej osoby [19]. Konstrukt ten w znacznym stopniu odpowiada za adaptacyjne funkcjonowanie jednostki, co z kolei przekłada się na wzrost ambicji i wysoką ocenę jakości życia. Orientacja pozytywna jest przeciwieństwem triady depresyjnej (poznawczej) A. Becka, tj. negatywnej wizji siebie, otaczającej rzeczywistości i przyszłości [20]. 
Nie wszyscy śmieją się z tych samych żartów, a różnice indywidualne w ogólnym poczuciu, jak i specyficznym stylu humoru mają swoje źródła m.in. w utrwalonych cechach psychicznych. Metaanaliza badań nad humorem w kontekście osobowościowej koncepcji „wielkiej piątki” wykazała silny związek pomiędzy adaptacyjnym humorem afiliacyjnym a podwyższoną ekstrawersją i obniżonym neurotyzmem [12]. Ten pozytywny styl humoru był również istotnym predyktorem ogólnego poczucia szczęścia i zadowolenia z siebie [21]. W badaniu Styśko-Kunkowskiej i Boreckiej [22], polegającym na ocenie zabawności prezentowanych tekstów, studenci o wyższym natężeniu ekstrawersji dostrzegali więcej humorystycznych aspektów niż ich introwertyczni koledzy. Ciekawych wyników dostarczyło także badanie Kuipera i Leite [23], w którym zadaniem uczestników była ocena osobowości nieznanych osób na podstawie informacji o preferowanych przez nich stylach żartów. Osoby charakteryzujące się pozytywnymi wzorcami humoru oceniane były jako bardziej przyjazne, towarzyskie i stabilne emocjonalnie niż osoby wykazujące humor agresywny czy samodeprecjonujący. Zależności między osobowością a poczuciem humoru zostały także potwierdzone danymi neurobiologicznymi. Okazuje się, że przepływ krwi w obszarach układu limbicznego kojarzonych z poczuciem humoru jest niższy u osób bardziej introwertycznych i neurotycznych [24].

\section{MATERIAtY I METODY}

Główny problem badawczy ująć można w postaci pytania o istnienie związków pomiędzy podstawowymi wymiarami osobowości a stylami poczucia humoru i siłą orientacji pozytywnej. W odpowiedzi na ten problem sformułowano następujące hipotezy badawcze:

1. Konstruktywne wzorce humoru i pozytywna orientacja są silniejsze u osób bardziej ekstrawertycznych i stabilnych emocjonalnie.

2. Nieadaptacyjne wzorce humoru i niższa pozytywna orientacja są silniejsze u osób bardziej neurotycznych i psychotycznych.

\section{Grupa i przebieg badania}

W badaniu udział wzięło 68 studentów Uniwersytetu Szczecińskiego i Pomorskiego Uniwersytetu Medycznego w Szczecinie (65,7\% kobiet i 34,3\% mężczyzn) w wieku 20-49 lat ( $\mathrm{M}=24,5$; $\mathrm{SD}=6,4)$. Dane zbierano w marcu $2016 \mathrm{r}$, a anonimowe badania grupowe trwały średnio 20-30 min. Po zapoznaniu się z założeniami badania ochotnicy proszeni byli o wypełnienie trzech kwestionariuszy.

\section{Narzędzia i zmienne}

Do pomiaru trzech zmiennych współwystępujących - osobowości, humoru i orientacji pozytywnej - zastosowano trzy wystandaryzowane narzędzia psychologiczne:

1. Kwestionariusz Osobowości Eysencka EPQ-R - narzędzie autorstwa H. Eysencka i S. Eysenck (2006), w polskiej adaptacji A. Jaworowskiej i wsp. (2011), mierzy trzy czynnikowe cechy osobowości - ekstrawersję-introwersję, neurotyzm i psychotyzm. Ponadto test wyposażony jest w dodatkową skalę kontrolną kłamstwa, określającą takie cechy jak poziom szczerości badanego, poziom zsocjalizowania i potrzebę społecznej aprobaty. Kwestionariusz składa się ze 106 pytań zamkniętych. Osoba badana udziela odpowiedzi poprzez wybranie jednej z dwóch rozłącznych alternatyw „tak” albo „nie” w zależności od tego, czy zawarta w pytaniu charakterystyka jest zgodna z obrazem osoby wykonującej test. Wyniki surowe, będące sumą diagnostycznych odpowiedzi w każdej podskali, przełożyć można na skalę stenową, uwzględniającą wiek i płeć osoby badanej [25]. W badaniu własnym, analogicznie jak w oryginalnym badaniu normalizacyjnym tego narzędzia, 3 skale osiągnęły bardzo satysfakcjonujący wskaźnik dokładności pomiaru $(\alpha>0,800)$, natomiast skala psychotyzmu wykazała nieco obniżoną rzetelność $(\alpha=0,614)$.

2. Kwestionariusz Stylów Humoru HSQ został opracowany przez zespół R. Martina w 2003 r. (polska adaptacja: E. Hornowska i J. Charytonik, 2011). W skład narzędzia wchodzą 4 niezależne skale mierzące poszczególne typy humoru - afiliacyjny, humor w służbie ego, agresywny oraz samodeprecjonujący. Kwestionariusz zgodnie z koncepcją R. Martina określa zróżnicowanie poczucia humoru wśród osób dorosłych, a badania potwierdzają jego rolę w kształtowaniu dobrostanu psychofizycznego jednostki. Narzędzie składa się z 32 twierdzeń opisujących powyższe style. Badany udziela odpowiedzi, posługując się 7-stopniową skalą (od 1 - „zdecydowanie nie zgadzam się” do 7 - „zdecydowanie zgadzam się”). Czas na wypełnienie kwestionariusza jest nieograniczony [17]. W badaniu własnym najwyższą dokładnością pomiaru cechowała się skala humoru samodeprecjonującego $(\alpha=0,711)$, zaś najniższą - humoru afiliacyjnego $(\alpha=0,681)$.

3. Skala Orientacji Pozytywnej jest krótką skalą autorstwa G. Caprara (2009) integrującą trzy elementy pozytywnego nastawienia - samoocenę, optymizm i życiową satysfakcję. Do polskich warunków została zaadaptowana przez M. Łagunę, P. Olesia i D. Filipiuk w 2011 r. Opisany konstrukt mierzy cechę latentną (ukrytą), która w sposób obserwowalny wyraża się m.in. w zwiększonej motywacji w dążeniu do realizacji wyznaczonych sobie celów. Skala zawiera 8 stwierdzeń, do których osoba badana ustosunkowuje się, korzystając z 5-stopniowej skali (od 1 - „zdecydowanie nie zgadzam się” do 5 - „zdecydowanie zgadzam się"). Badanie nie jest ograniczone limitem czasu, zaś wynik interpretowany jest wprost - im wyższa suma punktów (maksymalnie 40), tym wyższy poziom pozytywnej orientacji [20]. W badaniu własnym skala ta osiągnęła zadowalający poziom rzetelności pomiaru $(\alpha=0,760)$.

\section{WYNIKI}

W celu weryfikacji hipotez badawczych posłużono się metodą korelacyjną, dobierając jako współczynnik rho Spearmana dla cech o rozkładach odbiegających od normalnego (orientacji pozytywnej, humoru afiliacyjnego i agresywnego) oraz r Pearsona dla pozostałych zmiennych. Różnice międzypłciowe 
zweryfikowano testem U Manna-Whitneya. Obliczenia przeprowadzono przy użyciu pakietu IBM SPSS Statistics. W tabeli 1 przedstawiono wyniki analizy korelacji, która ujawniła 7 w pełni istotnych $(\mathrm{p}<0,05)$ związków zachodzących pomiędzy osobowością a humorem.

TABELA 1. Współczynniki korelacji pomiędzy cechami osobowości a poczuciem humoru

\begin{tabular}{lcccc} 
& \multicolumn{4}{c}{ Cechy osobowości } \\
\cline { 2 - 5 } Humor & $\begin{array}{l}\text { ekstra- } \\
\text { wersja }\end{array}$ & neurotyzm & psychotyzm & kłamstwo \\
\hline Ogólny & $0,397^{*}$ & $-0,020$ & 0,237 & $-0,153$ \\
\hline Afiliacyjny & $0,255^{*}$ & $-0,083$ & 0,132 & $-0,323^{*}$ \\
\hline W służbie ego & 0,229 & $-0,351^{*}$ & 0,003 & 0,080 \\
\hline Agresywny & $0,366^{*}$ & 0,137 & $0,267^{*}$ & $-0,084$ \\
\hline $\begin{array}{l}\text { Samodeprecjo- } \\
\text { nujący }\end{array}$ & 0,175 & $0,439^{* *}$ & 0,226 & 0,063
\end{tabular}

${ }^{*} p<0,01 ;{ }^{* *} p<0,001$

Pomiędzy poszczególnymi wymiarami osobowości a wybranymi stylami poczucia humoru zaobserwowano zarówno dodatnie, jak i ujemne zależności. Związki te wykazują znaczną istotność $(\mathrm{p}<0,01)$, a przy tym niskie i umiarkowane siły.

Cecha ekstrawersji była dodatnio skorelowana z ogólną miarą poczucia humoru ( $\mathrm{r}=0,397)$, pozytywnym humorem afiliacyjnym oraz agresywnym stylem żartów. Większą skłonnością do tej negatywnej formy humoru odznaczały się również osoby o wyższym poziomie cechy psychotyzmu (rho = 0,267). Wśród bardziej neurotycznych badanych najbardziej typowy okazał się humor samodeprecjonujący $(r=0,439)$. Wynika z tego, że niestabilność emocjonalna i negatywna uczuciowość związane są z używaniem humoru w celu umniejszenia własnej wartości. Ponadto im wyższym natężeniem neurotyzmu cechowali się badani, tym rzadziej korzystali z pozytywnego humoru w służbie ego. Dodatkowo zaobserwowano ujemną korelację pomiędzy humorem afiliacyjnym a skalą kontrolną kłamstwa (rho = -0,323). Oznacza to, że tę pozytywną formą żartu chętniej posługiwały się osoby bardziej nonkonformistyczne, o niższej potrzebie społecznej aprobaty.

W analogiczny sposób zweryfikowano związki pomiędzy osobowością a siłą orientacji pozytywnej (tab. 2).

W odniesieniu do pozytywnej orientacji zaobserwowano jedną istotną statystycznie zależność o ujemnym kierunku i umiarkowanej sile. Okazuje się, że im wyższym poziomem neurotyzmu cechowały się osoby badane, tym niższy był ich poziom orientacji pozytywnej (rho $=-0,459)$. Chwiejna

TABELA 2. Współczynniki korelacji pomiędzy cechami osobowości a orientacją pozytywną

\begin{tabular}{lcccc} 
& \multicolumn{4}{c}{ Cechy osobowości } \\
\cline { 2 - 5 } & $\begin{array}{l}\text { ekstra- } \\
\text { wersja }\end{array}$ & neurotyzm & psychotyzm & kłamstwo \\
\hline $\begin{array}{l}\text { Orientacja } \\
\text { pozytywna }\end{array}$ & 0,143 & $-0,459^{\#}$ & $-0,214$ & $-0,048$ \\
\hline
\end{tabular}

$\# p<0,001$ i negatywna emocjonalność sprzyja bardziej negatywnej ocenie siebie, otoczenia i przyszłości. Im mniej neurotyczni byli badani studenci, tym wyższe były ich samoocena, optymizm i satysfakcja z życia.

Dodatkowo sprawdzono, czy takie cechy jak wiek i płeć różnicują badanych pod kątem poczucia humoru i orientacji pozytywnej. W tabeli 3 przedstawiaono wyniki analizy korelacji pomiędzy wiekiem a humorem i nastawieniem.

TABELA 3. Współczynniki korelacji pomiędzy wiekiem a poczuciem humoru i orientacją pozytywną

\begin{tabular}{ccccccc}
\cline { 3 - 5 } ogólny & $\begin{array}{c}\text { afilia- } \\
\text { cyjny }\end{array}$ & $\begin{array}{c}\text { w stużbie } \\
\text { ego }\end{array}$ & $\begin{array}{c}\text { agre- } \\
\text { sywny }\end{array}$ & $\begin{array}{c}\text { samode- } \\
\text { precjo- } \\
\text { nujący }\end{array}$ & $\begin{array}{c}\text { Orientacja } \\
\text { pozytywna }\end{array}$ \\
\hline Wiek & $-0,355^{*}$ & $-0,181$ & $-0,062$ & $-0,139$ & $-0,405^{* *}$ & 0,059 \\
\hline
\end{tabular}

${ }^{*} p<0,01 ;{ }^{* *} p<0,001$

Okazuje się, że ogólny poziom humoru spada wraz ze wzrostem wieku osób badanych, choć zależność ta nie jest silna (rho $=-0,355$ ). Wprawdzie pozytywne formy żartu nie umacniają się z biegiem lat, wykazano jednak, że wraz z wiekiem umiarkowanie słabnie skłonność badanych do posługiwania się negatywnym humorem samodeprecjonującym (rho $=-0,405)$. Oznacza to, że młodsi uczestnicy badania byli bardziej skorzy do żartowania z samych siebie w celu pozyskania aprobaty otoczenia, zaś wraz z wiekiem ta niekonstruktywna forma żartu ulega osłabieniu.

Ponadto, podobnie jak w innych populacjach [26, 27], w grupie zachodziły różnice świadczące o większym nasileniu humoru agresywnego u mężczyzn $(Z=2,263 ; p=0,024)$.

\section{DYSKUSJA}

Przeprowadzone badanie pozwoliło zaobserwować związki zachodzące pomiędzy wybranymi dyspozycjami osobowościowymi a ogólnym wskaźnikiem poczucia humoru oraz nasileniem jego czterech typów. Szczególnie dwa wymiary osobowości okazały się istotnie wiązać z określonymi stylami żartów, a jeden z nich dodatkowo związany był z siłą pozytywnej orientacji na siebie i świat zewnętrzny.

Opisywane zależności odnoszą się do grupy młodych, studiujących kobiet i mężczyzn, a uzyskane wyniki są podobne do rezultatów publikowanych przez innych autorów, wskazując na korzystne znaczenie podwyższonej ekstrawersji i obniżonego neurotyzmu dla pozytywnego nastawienia i dobrego humoru. Bardziej ekstrawertyczni studenci nieco chętniej posługiwali się też agresywnym stylem żartów, podobnie jak osoby o wyższym nasileniu cechy psychotyzmu.

Jak się okazuje, otwartość na świat zdarzeń zewnętrznych sprzyja ogólnemu poczuciu humoru oraz jego pozytywnemu afiliacyjnemu stylowi, a jednocześnie łączy się z agresywnym stylem żartu. Posługiwanie się sarkazmem i ironią połączone z nieprzykładaniem należytej wagi do wywieranych przykrych odczuć okazało się nieco bardziej nasilone u osób 
o wyższym natężeniu dwóch niezależnych od siebie cech osobowości. Zatem z jednej strony wiązało się z prospołeczną postawą i dążeniem do kontaktów interpersonalnych, a z drugiej ze społeczną izolacją i niedostosowaniem. Ponadto taką formą żartu częściej posługiwali się mężczyźni.

Z konstruktywnym wzorcem humoru wiązała się większa równowaga emocjonalna i niższa potrzeba społecznej aprobaty. Badani o tych cechach wykazywali większą zdolność do zdystansowania się wobec trudnych sytuacji i dostrzegania w nich humorystycznych akcentów, co umożliwia lepsze radzenie sobie z negatywnymi emocjami. Osoby o niższym poziomie neurotyzmu były nastawione bardziej pozytywnie, a przy tym mniej skłonne do ośmieszania samych siebie w celu pozyskania przychylnej reakcji otoczenia. Bez względu na osobowość tendencja do samodeprecjacji spadała wraz z wiekiem.

Zaprezentowane wyniki odnoszą się do młodych, uczących się osób, a stosunkowo nieduża wielkość grupy stanowi pewne ograniczenie badania. Uzyskane wyniki korespondują jednak z doniesieniami z najnowszych badań, prowadzonych na większych grupach studentów i osób dorosłych. Na przykład Zeigler-Hill i wsp. wśród ponad 500 studentów badanych Kwestionariuszem Osobowości DSM-V (PID-5) m.in. pod kątem nasilenia cech neurotyzmu i psychotyzmu zaobserwowali, że osoby mniej stabilne emocjonalnie cechowały się niższym nasileniem obu pozytywnych wzorców humoru i większą samodeprecjacją, podczas gdy cecha psychotyzmu była słabo związana z humorem agresywnym [28]. Z kolei Ford i wsp. na grupie ponad 200 osób dorosłych wykazali, że cecha ekstrawersji wiązała się zarówno z pozytywnym humorem afiliacyjnym i w służbie ego, jak i z niekonstruktywnym humorem agresywnym [29]. Związki obserwowane w badaniach na bardziej reprezentatywnych grupach cechowały się bardzo podobnymi (słabymi) siłami jak korelacje zaobserwowane w badaniu własnym.

Uzyskane rezultaty wskazują, że osobowościowa otwartość na ludzi i stabilność emocjonalna są korzystnie powiązane $\mathrm{z}$ adaptacyjnymi wzorcami poczucia humoru i bardziej pozytywnym nastawieniem do siebie i świata. Taki profil osobowości może predysponować nie tylko do większej satysfakcji z życia, ale i do lepszego zdrowia. Między innymi Wilson i wsp. wykazali, że właśnie podwyższona ekstrawersja i obniżony neurotyzm korzystnie wiążą się z podejmowanymi zachowaniami prozdrowotnymi, przekładając się na lepszą kondycję psychofizyczną [30].

\section{WNIOSKI}

1. Konstruktywne poczucie humoru, optymizm oraz pozytywne wartościowanie siebie i życia uznawane są za czynniki zdrowia, które sprzyjają ogólnemu poczuciu dobrostanu, a także wspomagają proces terapii zarówno zaburzeń psychicznych, jak i chorób fizycznych.

2. Różnice indywidualne w nasileniu ogólnego poczucia i specyficznych stylów humoru związane są z utrwalonymi cechami osobowości, które predysponują do bardziej lub mniej konstruktywnych wzorców zachowań.
3. Korzystną cechą okazała się ekstrawersja - bardziej otwarci i towarzyscy studenci wykazywali ogólnie większe poczucie humoru, przy czym posługiwali się żartami zarówno w celu budowania pozy tywnych relacji i atmosfery, jak i w bardziej agresywnej formie. Również korzystna wydaje się postawa społecznej autonomii, pewna doza nonkonformizmu, nieskłonność do uzależniania swoich decyzji i samopoczucia od opinii innych ludzi - wśród takich osób dominował humor afiliacyjny, wyrażający ogólną wesołość, która rozładowuje napięcie i wzbogaca kontakty międzyludzkie.

4. Niekorzystną cechą okazał się przede wszystkim neurotyzm - osoby o negatywnej i chwiejnej emocjonalności wykazywały niższy optymizm, samoocenę i zadowolenie z życia, były bardziej skore do ośmieszania samych siebie w celu pozyskania przychylności innych ludzi, a w dodatku rzadziej dostrzegały w humorze narzędzie do łagodzenia nerwowego napięcia i podnoszenia samooceny. Niekorzystne związki dostrzeżono także w odniesieniu do cechy psychotyzmu, który wiązał się wyłącznie z agresywnym stylem żartu.

\section{PIŚMIENNICTWO}

1. Marziali E, McDonald L, Donahue P. The role of coping humor in the physical and mental health of older adults. Aging Ment Health 2008;12(6):713-8. doi: 10.1080/13607860802154374.

2. Craun SW, Bourke ML. The use of humor to cope with secondary traumatic stress. J Child Sex Abus 2014;23(7):840-52. doi: 10.1080/10538712.2014.949395.

3. Chopik WJ, Kim ES, Smith J. Changes in optimism are associated with changes in health over time among older adults. Soc Psychol Personal Sci 2015;6(7):814-22. doi: 10.1177/1948550615590199.

4. Schrank B, Brownell T, Tylee A, Slade M. Positive psychology: an approach to supporting recovery in mental illness. East Asian Arch Psychiatry 2014;24(3):95-103.

5. Karimi F, Jamali S, Karimi T, Hemati F, Safari F. The effect of laughter therapy on reducing depression in female students of Payam-e-Noor University of Ilam. Reef Resources Assessment and Management Technical Paper 2014;40(1):561-6.

6. Parnowska D, Braniecka A, Radomska A. Poczucie humoru w schizofrenii - zdolność do odbioru komizmu i możliwości jego wykorzystania w oddziaływaniach terapeutycznych. Psychiatr Pol 2013;47(5):945-56.

7. Bennett PN, Parsons T, Ben-Moshe R, Weinberg M, Neal M, Gilbert K, et al. Laughter and humor therapy in dialysis. Semin Dial 2014;27(5):488-93. doi: $10.1111 /$ sdi.12194.

8. Bennett MP, Zeller JM, Rosenberg L, McCann J. The effect of mirthful laughter on stress and natural killer cell activity. Altern Ther Health Med 2003;9(2):38-45.

9. Strelau J. Różnice indywidualne. Warszawa: Scholar; 2015.

10. Millon T, Davis R. Zaburzenia osobowości we współczesnym świecie. Warszawa: Instytut Psychologii Zdrowia; 2005.

11. McCrae RR., Costa PT. The five-factor theory of personality. In: John OP, Robins RW, Pervin LA, editors. Handbook of personality. Nowy Jork: Guilford Press; 2008.

12. Mendiburo-Seguel A, Paez D, Martinez-Sanchez F. Humor styles and personality: A meta-analysis of the relations between humor styles and the Big Five personality traits. Scand J Psychol 2015;56(3):335-40. doi: 10.1111/sjop.12209.

13. Hall CS, Lindzey G, Campbell JB. Teorie osobowości. Warszawa: PWN; 2010.

14. Pervin LA, John OP. Osobowość: teoria i badania. Kraków: Wyd. Uniw. Jagiellońskiego; 2011.

15. Cann A, Collette C. Sense of humor, stable affect, and psychological wellbeing. EJOP 2014;10(3):464-79. doi.org/10.5964/ejop.v10i3.746.

16. Rusek A. Wielowymiarowość humoru. Innow Psychol 2012;1(1):117-27. 
17. Martin RA, Puhlik-Doris P, Lersen G, Gray J, Weir K. Individual differences in uses of humor and their relation to psychological wellbeing: Development of the Humor Styles Questionnaire. J Res Personal 2003;37:48-75. doi:10.1016/S0092-6566(02)00534-2.

18. Hornowska E, Charytonik J. Polska adaptacja Kwestionariusza Stylów Humoru (HSQ) R. Martina, P. Puhlik-Doris, G. Larsena, J. Gray i K. Weir. Stud Psychol 2011;49(4):5-22.

19. Caprara GV. Positive orientation: Turning potentials into optimal functioning. Bull Eur Health Psychol 2009;11(3):46-8.

20. Łaguna M, Oleś P, Filipiuk D. Orientacja pozytywna i jej pomiar: Polska adaptacja Skali Orientacji Pozytywnej. Stud Psychol 2011;49(4): 47-54.

21. Yue XD, Liu KW, Jiang F, Hiranandani NA. Humor styles, self-esteem and subjective happiness. Psychol Rep 2014;115(2):517-25. doi: 10.2466/07.02. PR0.115c18z6.

22. Styśko-Kunkowska MA, Borecka D. Extraversion and evaluation of humorous advertisements. Psychol Rep 2010;106(1):44-8. doi: 10.2466/ PR0.106.1.44-48.

23. Kuiper NA, Leite C. Personality impressions associated with four distinct humor styles. Scand J Psychol 2010;51(2):115-22. doi: 10.1111/j.14679450.2009.00734.x
24. Mobbs D, Hagan CC, Azim E, Menon V, Reiss AL. Personality predicts activity in reward and emotional regions associated with humor. Proc Natl Acad Sci U S A 2005;102(45):16502-6. doi: 10.1073/pnas.0408457102.

25. Matczak A, editor. Podręcznik do Skal Osobowości Eysencka (EPS dla dorosłych). Warszawa: Pracownia Testów Psychologicznych Polskiego Towarzystwa Psychologicznego; 2011.

26. Liu KW. Humor styles, self-esteem and subjective happiness. Discovery - SS Student E-Journal 2012;1:21-41.

27. Chen GH, Martin RA. A comparison of humor styles, coping humor, and mental health between Chinese and Canadian university students. Humor 2007;20(3):215-34.

28. Zeigler-Hill V, McCabe GA, Vrabel JK. The dark side of humor: DSM-5 pathological personality traits and humor styles. EJOP 2016;12(3):363-76. doi: 10.5964/ejop.v12i3.1109.

29. Ford TE, Lappi SK, Holden CJ. Personality, humor styles and happiness: Happy people have positive humor styles. EJOP 2016;12(3):320-37. doi: 10.5964/ejop.v12i3.1160.

30. Wilson KE, Das BM, Evans EM, Dishman RK. Structural equation modeling supports a moderating role of personality in the relationship between physical activity and mental health in college women. J Phys Act Healts 2016;13(1):67-78. doi: 10.1123/jpah.2014-0455. 